Newfoundland and Labrador Studies

\title{
From Parmenius to Paton: 350 Years of Classical Learning in (and about) Newfoundland
}

\section{Mark Joyal}

Volume 33, numéro 2, 2018

URI : https://id.erudit.org/iderudit/1058076ar

DOI : https://doi.org/10.7202/1058076ar

Aller au sommaire du numéro

\section{Éditeur(s)}

Faculty of Arts, Memorial University

\section{ISSN}

1719-1726 (imprimé)

1715-1430 (numérique)

Découvrir la revue

\section{Citer cet article}

Joyal, M. (2018). From Parmenius to Paton: 350 Years of Classical Learning in (and about) Newfoundland. Newfoundland and Labrador Studies, 33(2).

https://doi.org/10.7202/1058076ar d'utilisation que vous pouvez consulter en ligne.

https://apropos.erudit.org/fr/usagers/politique-dutilisation/ 


\title{
From Parmenius to Paton: 350 Years of Classical Learning in (and about) Newfoundland
}

Mark Joyal

\author{
In memoriam collegarum meorum \\ Ioannis Bruce, Iacobi Butrica, Ioannis Whittaker
}

Since the founding of Memorial University College (MUC) in 1925 and the establishment of Memorial University of Newfoundland (MUN) in 1949, the study of the ancient Greeks and Romans — their languages, history, literature, art, philosophy, religious life, and so on - has been pursued in Newfoundland almost entirely in those institutions. The first Principal of MUC was John Lewis Paton, a Cambridge-educated classical scholar and famous headmaster with a long, distinguished career in England already behind him. With Paton at the helm, the place of classical studies in the College's curriculum seems to have been assured. ${ }^{1}$ Yet, Newfoundlanders' interest in the ancient civilizations did not emerge suddenly, imposed from outside, a little less than a hundred years ago. On the contrary, there is much to be learned about the nature and breadth of this interest and the contexts in which it was expressed during most of the nineteenth century and the first twenty-five years of the twentieth. What is more, classical learning played an essential role in the British narrative about Newfoundland for nearly half a century, from the time of Sir Humphrey Gilbert's voyage in 1583. Even the history of Newfoundland's first school preserves evidence for the presentation of ancient methods and ancient wisdom in the first half of the eighteenth century. 
Much of the material that enables this story to be told is today unrecognized, forgotten, or only dimly remembered; even what is known has not been placed in a meaningful context. This is not to say that the history of Newfoundland is replete with evidence for classical learning. ${ }^{2}$ There are, admittedly, long barren stretches in this story, especially over the last two-thirds of the seventeenth century and most of the eighteenth, for which only fruitless speculation seems possible. It is with justification that D.W. Prowse wrote in 1896:

\begin{abstract}
Alas! for the glory of our Island, for the praise of our discoverer, there are no portraits to discuss, no noble Isabella la Católica, no devoted friar. No golden haze of romance surrounds our earliest annals. The story of the discovery of Newfoundland and North America, as told by the Cabots, is as dull as the log of a dredge-boat. Every picturesque element is eliminated from it, and the great voyage, so pregnant with moral and material results, is brought down to the low level of a mere trading adventure. ${ }^{3}$
\end{abstract}

There is, for instance, nothing from or about Newfoundland of the sixteenth century to the middle of the nineteenth to compare in quantity with what we find in contemporary Mexico and Latin America. There, seven universities were established in the sixteenth century alone, the earliest in Santo Domingo, Lima, and Mexico City, ${ }^{4}$ and about another dozen in the century that followed. Latin enjoyed enormous prestige in colonial Mexico and Latin America and was widely used as a diplomatic language. One of the earliest activities in the Royal and Pontifical University of Mexico was the training in the Latin language of young members of the native Mexican elite, perhaps most famously Juan Badiano, who in 1552 translated into Latin an Aztec text on medicinal herbs (the Libellus de Medicinalibus Indorum Herbis). Nor is there anything like the vast body of writing in Latin produced in New France in the seventeenth and eighteenth centuries - history, poetry, and scientific writing, among other genres and forms - composed especially but 
not only by Jesuit missionaries. Here, for instance, the first history of Canada (that is, New France) was written, in Latin, in $1656 .{ }^{5}$

More than anything else, the lack of permanent, large-scale immigration into Newfoundland before the late eighteenth century accounts for the shortage of material. But it is a shortage, not a complete absence. This paper concentrates mainly on what I would identify as the three principal periods or threads in the story: in part I, the Latin "embarkation" poem of 1582 by Stephen Parmenius, as well as the efforts by Richard Eburne, William Vaughan, Robert Hayman, and a few others to promote Newfoundland to the English (most of this work was composed in England, not Newfoundland); in part II, the evidence for an encounter with classical material in the earliest schools in Newfoundland, and the much more abundant evidence for the teaching and learning of Greek and Latin in Newfoundland schools between around 1800 and 1925; and in part III, the often scattered, sometimes latent, information that demonstrates the presence of classical learning in Newfoundland society in the nineteenth and early twentieth centuries. At first sight these elements in the story look unrelated, but as I hope to show, they are connected in some rather surprising ways. ${ }^{6}$

\section{Promotion and Plantation}

Our point of departure is with Stephen Parmenius, a Hungarian from Buda who was born probably between 1555 and 1560 . As a youth in Buda, he received training in Greek and Latin. He left his home in 1579, travelled to Heidelberg (and perhaps elsewhere) to continue his education, and by 1581 was in Oxford, where he made the acquaintance of several eminent people. Most consequentially, in England he met Sir Humphrey Gilbert, whom he accompanied on his voyage to Newfoundland in 1583. He perished when the ship on which he was sailing, the Swallow, ran aground off Sable Island on 29 August 1583; less than two weeks later, Sir Humphrey died at sea aboard the Squirrel, on the return voyage to England. ${ }^{7}$ 
All of Parmenius's surviving works are in Latin, and two are especially relevant to the subject of Newfoundland: one is a classicizing poem in 330 dactylic hexameters, written in England, about Sir Humphrey Gilbert's imminent voyage to Newfoundland; the other is a letter to Richard Hakluyt the younger, an important promoter of colonization in North America, which Parmenius wrote in St. John's on 6 August 1583. The letter is of tremendous interest for its description of the harbour and features of the surrounding area, some still familiar today, others altered by the passage of time: for example, the super-abundance of pine trees everywhere, the variety of berries and tall grasses, the appearance of white bears, ${ }^{8}$ and, of course, the inexhaustible supply of fish (piscium inexhausta copia). Early in the letter, in common late Renaissance fashion, Parmenius incorporates a Greek

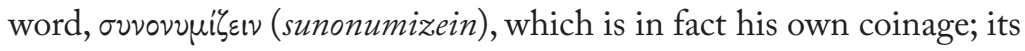
meaning is, apparently, "to speak in synonyms" or "to say the same thing in different words."

The historian of the European exploration of North America will be most interested in this letter, which is, after all, a dated eyewitness account, but the classical scholar is bound to be drawn instead to the

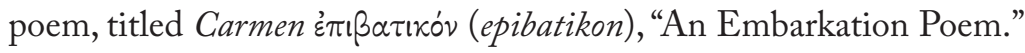
Obviously Parmenius was eager to demonstrate that he knew Greek - hence the insertion of Greek words at the outset of both the letter

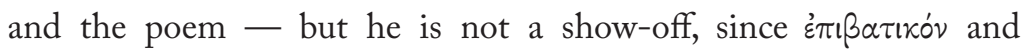

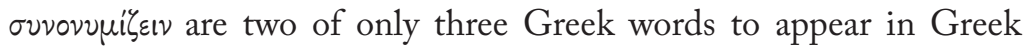
script in his writings. ${ }^{9}$ Quinn and Cheshire think that his misuse in

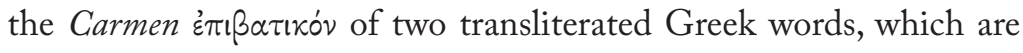
metrically intractable in dactylic hexameter, may be evidence of his imperfect knowledge of the language, but this standard sets the bar rather high for a sixteenth-century student of the language. ${ }^{10}$

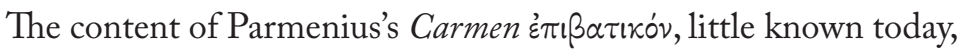
deserves to be set out; it is essentially as follows:

lines 1-26: Good fortune, a radiant sky, calm seas favour the voyages of Sir Humphrey Gilbert to unknown places. 
27-36: England is now pre-eminent among all other lands; new settlements must be found.

37-51: Leave Europe, Asia, and Africa for Hercules; the new land is for Sir Humphrey.

52-69: You will encounter a new race of people. Will this be the start of a Golden Age, about which the ancient poets (vates; see n. 12 below) have spoken?

70-86: But in the pagan lands of Eastern Europe it is an Age of Iron, or of Rock.

87-156: For the British, however, it is a Golden Age. Barbarous people will come together into cities and live in peace, under laws; the earth will yield its wealth at the cost of little sweat.

157-68: If only I could join the voyage and sing of this Golden race!

169-93: Queen Elizabeth will watch over Gilbert as Athena watched over Jason. From women like her, Hector, Achilles, and other heroes were born.

194-236: Other emperors rule in fear; Elizabeth is merciful, lawful, wise, peaceful. The world longs to obey your command.

237-76: High-minded youth must sail with Gilbert; they must relieve America of its oppression (i.e., by the Spanish Catholics).

277-98: A catalogue of explorers: Sir Hugh Willoughby, Stephen and William Borough, Anthony Jenkinson, Martin Frobisher, Sir Francis Drake.

299-330: Monsters and giants await, worthy of Hercules and Bacchus. Columbus and Cabot have shown the way to a land of moderate climate. I hope that peace will come through you.

A few fundamental themes are apparent even in this general sketch: for the people of Britain, living under the wise rule of Queen Elizabeth, it is a Golden Age; in both geographical extent and achievement, Sir Humphrey's voyage will rival the ones that heroes like Jason 
and Hercules/Heracles made (Jason in pursuit of the Golden Fleece, Heracles to complete his 12 labours); in the new land he will find not Golden Fleece but, again, a Golden Age. Given these themes, given the fact that Parmenius had at the time of writing never been to the New World, and given the language in which he wrote, we expect him to have relied on certain classical works, especially in Latin, that are most pertinent to these topics. ${ }^{11}$ And that is unmistakably what we find: above all, these works are the Fourth (so-called "Messianic") Eclogue and the second and fourth books of the Georgics, by the Roman poet Virgil (70-19 BC), and Book 1, lines 89-162, of the Metamorphoses by the Roman Ovid (43 BC-AD 17), each of which deals with the theme of a Golden Age, first presented centuries earlier by the Greek poet Hesiod (eighth century BC). There are also clear reminiscences of the "Roman Odes" of the poet Horace (65-8 BC), that is, the first six poems in Book 3 of his Odes; but whereas Horace in these Odes exalts the Emperor Augustus, Parmenius praises Queen Elizabeth. ${ }^{12}$ In tracing precise verbal sources and correspondences Quinn and Cheshire in their commentary have understandably picked the low-hanging classical fruit. ${ }^{13}$ This is not the place for detailed philological discussion of that kind, but I suspect that many more signs of Parmenius's dependence on the above and other classical models await detection. ${ }^{14}$ However that may be, the simple point ought to be made that his use of Virgil, Ovid, and Horace is a reflection of the fact that these were the most widely read Roman authors during his lifetime and for long after.

Despite Humphrey Gilbert's enterprise, and despite Parmenius's imagination, artistic ability, and promotion of the project, no settlement would be established or attempted in the quarter-century that followed. Within months of the failure, Sir George Peckham, one of Sir Humphrey's partners in the plan to create a settlement, saw the need to disseminate a promotional defence of colonization, which he entitled $A$ true report of the late discoueries, and possession taken in the right of the Crowne of England of the Newfound lands, By that valiant and worthy Gentlemen, Sir Humfrey Gilbert, Knight. Here Peckham 
claims to have deliberated with himself not simply about the expediency of the plan but about its morality as well: possession of Newfoundland is beneficial to the British people, but is it right and lawful?: ${ }^{15}$ To settle the question, he appeals not to Biblical authority but, uniquely within this work, to a classical lesson he extracts from Plutarch's (c. AD 45c. 120) Life of Themistocles (20). The story involves the early fifth-century BC Athenian statesman Themistocles and his great rival Aristides, nicknamed "the Just" for his unmatched rectitude and truthfulness (my own translation follows):

Themistocles had an even greater plan in mind concerning the Athenian naval force. When the Greek fleet, after Xerxes' departure, had put in at Pagasae and was spending the winter there, he gave a speech before the Athenians, saying that he had a certain scheme which would be useful and salutary for them, but which could not be divulged in public. So the Athenians told him to explain it to Aristides alone and, if he approved of it, to carry it out. Themistocles explained to Aristides that he was planning to burn the Greek fleet. Aristides went before the people and said that no scheme was more advantageous or more iniquitous than the one which Themistocles was planning to carry out. So the Athenians on this account ordered Themistocles to abandon it.

Here are Sir George's reflections on this story:

I drewe my selfe into a more deepe consideration of this late vndertaken Voyage, whether it were as well pleasing to almightie God, as profitable to men; as lawfull, as it seemed honourable: as well gratefull to the Sauages as gainefull to the Christians. And vpon mature deliberation I found the action to be honest and profitable, and therefore allowable by the opinion of Aristides if he were now aliue. 
Peckham invokes Aristides as a higher authority, but he never explains bow he reached the conclusion that he did or why Aristides necessarily would have arrived at that same conclusion. In this case the classical model is adduced to lend an air of integrity to Peckham and his decision, and perhaps to impress his audience, but nothing in the ancient lesson logically justifies his opinion.

It was not until 1607 that Jamestown became the first English settlement in the Americas. The second, in 1610, was Cupids, Newfoundland, the project of the Newfoundland Company, which was made up of London and Bristol merchants, one of whom was John Guy, Cupids' first governor. The story of the attempts at settlement on the Avalon Peninsula between 1610 and the late 1620s is well known and need not detain us long. ${ }^{16}$ There was some initial success at Cupids, but it faltered, Guy lost interest and commitment, and by the early 1620s it had essentially failed. Ten miles north of Cupids, however, another settlement took root in what is now Harbour Grace. Its first and only governor, from 1618, was Robert Hayman. In 1616 the Welshman Sir William Vaughan purchased the southern part of the Avalon Peninsula, named the area Cambriol, "Little Wales," and the next year sent out some settlers to Aquaforte, where they fared poorly. In 1618 he appointed the experienced Richard Whitbourne to be governor of this settlement, and Whitbourne moved it a little south from Aquaforte to Renews, but it survived only a few years. More successful was the settlement that Sir George Calvert (Lord Baltimore) initiated in 1621 in Ferryland, just north of Aquaforte, where he also lived with his family from 1627 to $1629 .{ }^{17}$

The intense efforts to build permanent settlements in Newfoundland faced many challenges, ${ }^{18}$ and these were confronted in promotional literature. Although few original copies of it now remain, Richard Eburne's A Plaine Pathway to Plantations, published in 1624, argues its case for settlement in the New World better than most works of its kind. It is a dialogue between Respire, a farmer, and Enrubie, a merchant. We do not know who Respire is or is intended to be, but the name Enrubie, at any rate, is a reverse spelling of Eburne. When Respire 
comes to visit him, Enrubie is reading for recreation a book on plantations in Newfoundland, "for want of better company and exercise," as he says. Respire hopes he is not bothering him. In fact, Enrubie wants him to stay and sit with him under a tree, if he has the time; Respire will stay, for Enrubie's sake. In broad outline the opening is reminiscent of Plato's Phaedrus: the shade-tree, the book, the wish to examine the book's contents, the need for exercise, the concern of each man over his partner's benefit and convenience all evoke the mise en scène of the Platonic work. Eburne was vicar of the parish church in Hemstridge, Somerset, and although he may have known Greek, he shows no sign of it. But no matter: he could without difficulty have read Plato in Latin, if not in Marsilio Ficino's translation of 1484, copies of which were everywhere by 1624 , then in the 1561 translation by Janus Cornarius, or in the superior translation by Jean de Serres (Serranus) in Henri Estienne's famous 1578 "Vulgate" edition of Plato. The point here is that Plato's Phaedrus was easily obtainable and accessible for the Greekless reader. ${ }^{19}$

Enrubie and Respire show themselves to be astonishingly erudite conversation partners. Enrubie draws constantly upon the Bible, of course, but he also quotes classical Latin sources generously, usually with accompanying translation, and in addition he refers frequently to well-known stories from the classical world (see Appendix 1). For example, Eburne cites Roman justifications for colonization as precedents for the settlement of Newfoundland, drawing upon passages from both Livy and Cicero in the process. In particular, he argues that immigration to Newfoundland will relieve demographic, economic, and other pressures currently being exerted on England. He was not the first to cite ancient support for just this purpose. Parmenius himself had earlier identified the problem (lines 27-36, 268-72), and in one of the prefatory poems written to commend Sir George Peckham's treatise (above), John Hawkins points out that the Romans, the Athenians, and the Greek contingent in Troy resorted to the same practice in less straitened circumstances (lines 11-20): 
The Romains when the number of their people grewe so great,

As neither warres could waste, nor Rome suffice them for a seate.

They led them forth by swarming troupes, to forraine lands amaine

And founded divers Colonies, unto the Romaine raigne.

Th'athenians us'de the like devise, the Argives thus have done,

And fierce Achilles Myrmidons when Troy was over runne.

But Rome nor Athens nor the rest, were never pestered so, As England where no roome remaines, her dwellers to bestow,

But shuffled in such pinching bondes, that very breath dooth lacke:

And for the want of place they craule one ore anothers backe. $^{20}$

Hawkins does not apply only historical precedent, as Eburne did, but even adduces Greek legend, suggesting, apparently (through mention of the Argives and Achilles' Myrmidons), that the Trojan War was a colonizing enterprise. ${ }^{21}$

Respire's role in Eburne's work is mainly to toss questions at Enrubie, which allow him to enlarge on the arguments for successful settlement, and all but one of the Latin quotations are from the merchant's mouth, not the farmer's, but Respire does show wit and insight. For instance, when the prospect is raised of inducing schoolteachers to settle in the New World, Respire holds that "scholars nowadays are most of them of a tender breed and such as will hardly brook the seas; and England is provided of many good means of maintenance for them and therefore they will be loath to seek after less and worse otherwhere."22

Without question the most remarkable work of propaganda in support of settlement came from the pen of the aforementioned William Vaughan, the founder of Little Wales (Cambriol). ${ }^{23}$ In 1626, 10 
years after his purchase of that part of the Avalon, and after a string of disasters, Vaughan published The Golden Fleece, a wandering, bloated, but in its own way impressive, allegorical treatise. ${ }^{24}$ It deserves our attention not because it tells us much that is precise about Newfoundland itself - it is doubtful that Vaughan ever visited the island - but because it is loaded with classical themes and references. ${ }^{25}$ Here Vaughan calls himself Orpheus junior, and his settlement Colchos; Apollo is the supreme, wise judge who holds court over all; and golden fleece await the entrepreneur. ${ }^{26}$ But Vaughan is truthful, for Newfoundland is not an E1 Dorado in the literal sense (Pt. 3, ch. 1):

This is our Colchos, where the Golden Fleece flourisheth on the backes of Neptunes sheepe, continually to be shorne. This is Great Britaines Indies, neuer to be exhausted dry. This pretious Treasure surmounts the Duke of Burgundies Golden Fleece, which he called after that name by reason of his large customs which he receiued from our English Woolls and Cloth in the Low Countries.

Parmenius, Peckham, Eburne, and Vaughan all wrote their works before or without setting foot in Newfoundland. Unencumbered by reality, they could readily idealize the project of settlement, portray the island as a place of potentially great wealth, and misrepresent the kind of world that would be created there. Often they did so by drawing upon literary sources or historical models from a remote GrecoRoman past. Robert Hayman's circumstances were different. ${ }^{27} \mathrm{He}$ lived in Harbour Grace as its governor from 1618, and while there he composed a book of epigrams on many themes, published in London in 1628, which he called Quodlibets, literally "What pleases (you)" or "What-you-wish." Hayman knew William Vaughan; they were both born in 1575, they both attended Oxford University, Hayman at Exeter College, Vaughan at Jesus College, and their compositions were both promotions of settlement in Newfoundland. Hayman's classical learning is occasionally on display in his verse; for instance, here he 
compares Newfoundland with Socrates (Book 2.94):

'Tis said, wise Socrates look't like an Asse;

Yet he with wondrous sapience filled was;

So though our Newfound-Land look wild, saluage,

She hath much wealth penn'd in her rustie Cage. ${ }^{28}$

The classical elements of a Golden Age freedom from labour, care, and want insinuate themselves into his poetry (Book 1.117):

Although in cloaths, company, buildings faire,

With England, New-found-land cannot compare:

Did some know what contentment I found there,

Alwayes enough, most times somewhat to spare,

With little paines, lesse toyle, and lesser care,

Exempt from taxings, ill newes, Lawing, feare,

If cleane, and warme, no matter what you weare,

Healthy, and wealthy, if men carefull are,

With much-much more, then I will now declare,

(I say) if some wise men knew what this were,

(I doe beleeue) they'd liue no other where. ${ }^{29}$

Hayman's original verse, however, is not the literary activity most relevant to the present study, for Hayman was a translator into English of a substantial number of the Latin epigrams by the prolific John Owen (c. 1564-c. 1622). Owen's epigrams achieved tremendous popularity in the seventeenth century, and he was clearly a Latinist of unusual, even astonishing, virtuosity who was familiar intimately with his ancient epigrammatical antecedents, above all the Roman poet Martial. ${ }^{30}$ Hayman's translational patterns and predilections must be the subject of a different study, ${ }^{31}$ but here it is worth contemplating the simple fact that before he travelled to Newfoundland, he made the decision to take with him a copy of Owen's epigrams, and once he was in Harbour Grace - on an island populated perhaps by nobody else who knew Latin - he dedicated a considerable part of his time to the translation 
of a contemporary work of Latin poetry. That seems an extraordinary thing, and a fair claim can be made that Hayman was one of the very first Latinists in North America. ${ }^{32} \mathrm{He}$ has not, however, received the recognition he deserves. ${ }^{33}$

\section{Classical Learning in the Schools of Newfoundland}

As far as we know, Newfoundland's earliest school was established in Bonavista a hundred years later, in 1727 . What can be said about its founding, its operation, and its curriculum has been well set out by Hans Rollmann and Bonita Power. ${ }^{34}$ The character and limited goals of this humble institution give us little reason to expect that we will find any classical content in its activities. And yet we can be confident that some of its pupils, at any rate, made at least a minimal acquaintance with ancient wisdom and educational methods. Early in its history the school adopted as a basic textbook Henry Dixon's The English Instructor; or, The Art of Spelling Improved, which was first published in 1728 and would be reprinted, sometimes in modified form, many times throughout the eighteenth century. ${ }^{35}$ Like other primers of its day (as well as those from as much as two centuries earlier), the sequence of instruction followed a well-established pattern. ${ }^{36}$ Children learned the alphabet, then a long list of syllables consisting of one or two consonants and a vowel, often in all possible permutations, and then monosyllabic and polysyllabic words (the latter comprising words of up to seven and eight syllables). Readings consisting of only monosyllables, and of monosyllables and disyllables, followed the monosyllabic and polysyllabic lists, respectively, all based on Biblical teaching. Many moralizing sentences and anecdotes then appear, frequently grouped in alphabetical order according to the first word of each sentence. Dixon's book ends with a series of fables, but the whole is heavily larded with Christian prayers and hymns.

This method for teaching children to read finds its origins in classical antiquity in nearly all its elements: the thorough learning of the alphabet at the outset, followed by most or all basic syllables; the introduction of 
monosyllabic and polysyllabic words (as in Dixon's work, the breaks between syllables were clearly marked); exercises in reading by means of single sentences and anecdotes chosen for their high moral content; and more advanced reading that involved, above all, selections from Homer's Iliad or Odyssey (the latter less frequently); fables (of Aesop or Babrius) were sometimes included. ${ }^{37}$ The advent of Christianity altered the content of the reading material (though not at first), but it did not change the fundamental method by which the material was delivered..$^{38}$

No eighteenth-century student would know that the way in which he or she was learning to read originated with the ancient Greeks and Romans. ${ }^{39}$ Those who progressed far enough into Dixon's The English Instructor, however, would be confronted explicitly with ancient material, both in the fables near the end of the book and in the sentences and anecdotes in earlier sections. For instance, faced with the challenge of writing sentences in single and double lines (monostichs and distichs) that begin with the letters $\mathrm{Q}, \mathrm{X}$, and $\mathrm{Z}$, the author drew upon classical material:

(1) Xenophon accounted the wise Man happy.

(2) Xant[h]ippe [wife of Socrates] brawls, while Socrates is still, / Yet ne'er was quiet, though she had her Will. ${ }^{40}$

The next section, "A collection of sentences" (again arranged in alphabetical order), includes anecdotes on Quintilian, Xenophon, Xenocrates, and Zeno (twice). Here are three examples:

- Quintilian, an accurate Judge of Men, was pleased with Boys who wept when their School-fellows out did them; for the Sense of Disgrace would make them emulous, and Emulation would make them Scholars.

- Xenocrates holding his Peace at some detracting Discourse, they asked him, Why he did not speak? Because, says he, I have sometimes repented of Speaking, but never of holding my Peace.

- [Zeno], hearing a young Man speak too freely, said, For this Reason 
we have Two Ears and but One Tongue, because we should hear much and speak little.

The arrangement of these sentences and anecdotes in alphabetical order according to first letter takes its inspiration from the sequence of the Latin Sententiae ("Sayings") of Publilius Syrus (died 43 BC).

Some of the material is classical in origin even if not obviously so. Many of the moralizing two-line epigrams are not original to Dixon but find their genesis in the Distichs of Cato (Disticha Catonis), which were composed (or compiled) in Latin probably in the third or fourth century AD and quickly became a staple of the European educational curriculum throughout late antiquity, the Middle Ages, the Renaissance, and after. ${ }^{41}$ Since Dixon's The English Instructor came to be printed and published in both England and America and achieved widespread use on both sides of the Atlantic, eighteenth-century Newfoundland students who learned from it were being provided with an educational and cultural experience similar to that offered to young people elsewhere in the English-speaking world. It was an experience heavily influenced by classical methods and content.

In the second half of the nineteenth century, right up to the founding of Memorial University College in 1925, the study and teaching of Latin and ancient Greek and of the ancient world in general were mainly the business of Newfoundland's schools, especially those in St. John's. ${ }^{42}$ Fred Rowe, the historian of education in Newfoundland, implied in 1952, though he did not claim outright, that Greek was taught in a school in St. John's for the first time in $1817 .{ }^{43}$ His evidence — an advertisement published in the first newspaper in St. John's, the Royal Gazette - seems to be reliable, and by the nature of the case we can suppose that Latin was taught to some students before that time, but only perhaps when the island's population began to increase rapidly, in the 1790s. Latin and ancient Greek were important elements in the curricula of three interdenominational schools that emerged in the 1840s, in St. John's, Harbour Grace, and Carbonear. ${ }^{44}$ By the middle of the nineteenth century, Latin had a secure place in the curriculum of 
the denominational schools in St. John's: the Roman Catholic schools, i.e., St. Bonaventure's College (males) and Littledale Academy (females); the Church of England Schools, i.e., the St. John's Collegiate School, later to become Bishop Feild College (males), and Bishop Spencer College (females); and the Methodist College. By contrast, the position of Greek was solid only at Bishop Feild and St. Bonaventure's. Teachers of Latin and Greek in all these schools frequently came from the British Isles and Ireland, usually with top-flight training. For instance, Charles Durnford Newman, a graduate of Wadham College, Oxford, arrived in 1844 to be the Collegiate School's first master. In 1858 William Cowper Maclaurin (variously spelled in our sources also as MacLauren, McLauren and McLaren) was appointed Professor of Classics at St. Bonaventure's by Bishop John Mullock on the recommendation of John Henry Newman, on whose advice Mullock relied for other appointments as well. ${ }^{45}$ Arriving at the end of our period was Maude Joyner, who began to teach at Bishop Feild College in 1921 - the first female teacher at Bishop Feild, but with some duties at Bishop Spencer - after receiving Firsts in both Greek and Humanity (i.e., Latin) in 1910 from the University of St. Andrews. ${ }^{46}$ At St. Andrews she would have been taught by John Burnet, the distinguished editor and interpreter of Plato (among other things), and by the equally brilliant but austere Wallace Lindsay. ${ }^{47}$ Her 10 years of further training and experience in Scotland made her an exceptionally well-qualified teacher of Classics.

That this kind of recruitment represented a pattern is neatly demonstrated by an entry in the inaugural issue of the Spencerian, the magazine of Bishop Spencer College, in 1921. It reproduced a threeact Latin script by two students, Dorothy Fraser (age 16) and Doris Mews (age 17), entitled Ecce Veniunt! Gaudeamus Igitur (Look, they are coming! Therefore let us rejoice). Here are the first few lines: ${ }^{48}$

Rectrix Collegii et Discipule [sic; read Discipulae] in litore stantes adventum magistrarum qui [sic, read quae] ex Anglia veniunt expectant. 
D. [= Discipula] Prima: Quam densa nebula in mari sedet.

D. Secunda: Magistrae Britannicae opinionem malam insulae nostrae accipient.

D. Prima: $\mathrm{O}$ adversam rem!

Rectrix: Navis nondum advenit; optemus ut tempestas melior fiat.

D. Tertia: Ecce pluit!

D. Secunda: Ita, mehercule!

Alas for Maude Joyner, who was one of the schoolmistresses (magistrae) from Britain so anticipated by Dorothy and Doris. Newfoundland would not be a golden isle for her, since she remained at Bishop Feild for only two years. ${ }^{49}$

An interesting, indeed a crucial, episode in the story of the teaching of ancient Greek in Newfoundland is connected with the advent of the Rhodes Scholarships in 1904, one of which has been allocated to Newfoundland every year since inception. The questions about the Scholarship by which school administrators in Newfoundland were initially seized included these: Should the Rhodes not be open mainly to students who were leaving school, and their maximum age be 19 ? Was it fair to Newfoundlanders that all candidates be required to have two years of undergraduate study behind them? And what of Oxford's requirement that students demonstrate a knowledge of Greek? William Blackall, then Headmaster of Bishop Feild College, wrote on these matters to W.T. Stead (1849-1912), friend of Cecil Rhodes and one of the trustees of his will..$^{50}$ Blackall received a reply in June 1903, which he published in The Feildian (10.9-10 [1903: 110]): "Did you see Mr. Parkin who has written a confidential report which I have read as to the best method of selecting Rhodes scholars? He made a tour through Canada and the United States and has now gone to South Africa." "Mr. Parkin" is Sir George Parkin, the indefatigable founding Secretary of the Rhodes Scholarship Trust, and a Canadian born in New Brunswick. ${ }^{51}$ Stead, for his part, was misinformed: Parkin had not yet been to Canada; the visit was still in prospect. It was a regrettable 
error, since Blackall became irate over what Stead told him, as we learn in the same issue of The Feildian (110):

\begin{abstract}
No, we did not see Mr. Parkin, nor have we seen anything of his confidential report! We consider Mr. Parkin has slighted Newfoundland. Mr. Rhodes thought the Colony deserving of three scholarships a year ${ }^{52}$ and we should like to learn how it is that Mr. Parkin has failed to visit the island and learn of its position and its difficulties in relation to the awarding of these magnificent scholarships. It looks as though Mr. Parkin thought any scheme that would suit other parts would, or must suit Newfoundland. As far as we have been able to learn Mr. Parkin is really engaged in trying to place as scholars at Oxford a class of men never intended by the benefactor - a crowd of colonial graduates of over probably 22 years of age.
\end{abstract}

In the next issue of The Feildian (11.3 [1904: 47]), cooler words were spoken by Canon William Pilot, then Superintendent of the Church of England schools, on what had come to be called locally "the Rhodes Scholarship question":

This only will I say, that whatever scheme is prescribed for Newfoundland, it must of necessity give a great impetus to the study of Latin and Greek in our colleges: and in my opinion these tend to develop more of the intellectual faculties, and discipline and develop them more efficiently than any other branch of higher studies.

The Methodist College, however, was much less pleased than Canon Pilot about the requirement that potential Rhodes Scholars demonstrate some attainment in Greek, to which he alludes above. In its magazine, The Collegian, the school's Headmaster, Robert Holloway, wrote (8.7-8 [1903: 161-162]): 
In the published announcement with respect to the qualifying examination for applicants for the Rhodes Scholarship we cannot fail to be struck with the preponderance given to the Classics.... For much-needed details we must wait until Dr. Parkin arrives. ... Unless the Trustees and their representatives carefully study the peculiar conditions of our Colony, and make such arrangements as those conditions call for, the Rhodes Scholarship will become a rich man's perquisite, a most undesirable result..$^{53}$

By March 1904 answers still had not emerged, and Blackall showed little sign that he had calmed down, even though he now knew that Parkin's visit was still to come (The Feildian 11.4-5 [1904: 76-77]):

\begin{abstract}
And still we are in the dark in relation to the conditions of eligibility and of competition for the Rhodes Scholarship for Newfoundland 1904 ! ... [T] he only reply that can be wrung from [the trustees] is to the effect that there is to be a qualifying examination of the same standard as that of Responsions, ${ }^{54}$ Oxford, in July; that the organizing Secretary of the Trust (Dr. G. Parker [ sic]) is coming here in the course of the next few months, and that all other details, even for 1904, must await his arrival! What is it to them if possible candidates shall be precluded for the want of definite information! What to them if strenuous young lads of the very type, probably, that Rhodes sought shall resign positions in order to prepare for the qualifying examination, only to find themselves precluded by some condition of which they were kept in ignorance until the last moment!
\end{abstract}

For its part, St. Bonaventure's showed no dismay about the Greek requirement, or about anything else to do with the Scholarship. It was from this school that Newfoundland's first Rhodes Scholar, Sydney Herbert, came in 1904; he had graduated from the College four years earlier and begun the study of Greek only six months before sitting for 
the entrance examination for the Rhodes (held in lieu of Responsions). ${ }^{55}$ Contemporary records indicate that at this time there was a pretty substantial bump in the number of students studying Greek at St. Bonaventure's, Bishop Feild, and the Methodist College, ${ }^{56}$ but when Oxford University dropped compulsory Greek in 1919, the death of the subject in Newfoundland's schools would follow soon after. ${ }^{57}$ Parkin had his own views about where the study of Greek currently was and where it was headed; they are contained in an unpublished short essay, "The study of Greek," which he wrote in 1905, the year after "the Rhodes Scholarship question." ${ }^{58}$ Latin, of course, continued to thrive in Newfoundland's schools long after Greek had given up the ghost. In fact, the watershed year for its demise, with concomitant impact on enrolment at MUN, was 1969. ${ }^{59}$

\section{Classical Learning in Newfoundland Society and Culture}

In 1882, Thomas Talbot published Newfoundland: or, A Letter addressed to a Friend in Ireland in relation to the Conditions and Circumstances of the Island of Nerwfoundland, with an especial view to emigration. Talbot had taught school in Harbour Grace, Carbonear, and St. John's - his subjects included the Greek and Latin languages - and he had also served as Representative in the House of Assembly for St. John's West. In this book he reflects on, among other things, the physical changes that St. John's had undergone since he first came to Newfoundland from Ireland 45 years earlier, in 1837:60

When I compare the present appearance and condition of St. John's with what it was, in these respects, when I first saw it, forty-five years ago, I cannot help feeling as if the wand of a magician had touched it, and converted it into an entirely different place. It was then a big, frowsy, fishing village, straggling and scrambling up the side of a broken, rugged hill, without plan or arrangement, save what $\mathrm{Na}^{-}$ ture gave in its unrestrained vagaries of swell and hollow, 
rock and ravine. Its streets were paths, its lanes were muddy water-channels; and its houses were wooden sheds, ragged, dusky, and repulsive. There was not one stone or brick house that I remember, except Government House.... The public buildings were few and mean ....

When he arrived in 1837 , the population of the island was about 75,000 and that of St. John's less than 15,000. By 1882, Newfoundland's population was approaching 200,000 and that of St. John's was about 30,000 . Talbot's judgement about the changing face of the city must have been influenced especially by the construction of a few neo-classical buildings and some others that show neo-classical influence. The single outstanding example is the Colonial Building, constructed in 1850 and home of the Newfoundland legislature until 1959. In 1882, residents of St. John's could see reflexes of classical architecture also in the façades of the Athenaeum, built on Duckworth Street to be the cultural centre of the city, ${ }^{61}$ the Customs House on Water Street, and the Library at St. Bonaventure's College, as well as in details on Devon Place, a grand home on Forest Road (c. 1845). Other structures postdate 1882: the Royal Bank and HSBC buildings on Water Street (1893, 1913), the Masonic Temple on Cathedral Street (1894), the St. John's Courthouse (1904), the Commercial Cable Company Building (1915), and the former Parade Street campus of Memorial University College (1924). ${ }^{62}$ Talbot had lived through the fire that devastated St. John's in 1846, so buildings of stone or brick promised permanence and greater security than those of wood, but in Newfoundland as everywhere else, these same qualities were projected also by the neo-classical style itself, especially as applied to institutional buildings.

Talbot, however, plays a larger role in our story. Apart from his activity as a schoolteacher and Member of the House of Assembly, he also wrote books, two of which were on classical subjects, while a third consisted of both translations of Greek and Roman poetry and original verse. ${ }^{63}$ The first was published in Montreal in 1872, entitled Ancient Philosophy; or, The Enchiridion of Epictetus, and Chrusa Epe [Golden 
Sayings] of Pythagoras - translated into prose and verse, with large and copious notes, explanatory of the different systems of the Grecian philosophy; and scriptural references in illustration of the moral precepts inculcated by these philosophers. A review of the book in the Montreal Gazette was reprinted in March 1873 in the St. John's Morning Chronicle. The reviewer was enthusiastic: "The land of fog can at length boast the possession of an accomplished classical scholar, and we, as brother colonists, share with the Newfoundlanders in the reflected honor that attaches to those countries celebrated for the genius and culture of their authors." There follow no substantive criticisms of his book, and we may suppose that Talbot was pleased with this review, and pleased as well to have his compatriots read it in the local paper. Then in 1881 his Enchiridion of Epictetus was given wider distribution through its publication in London, and another of his books was also published there in the same year, entitled Greece and the Greeks; or, a Historic Sketch of Attic Life and Manners. These books were reviewed (without attribution) in England in the Saturday Review of Politics, Literature, Science and Art. ${ }^{64}$ Both reviews are remorseless; the opening of the second provides a flavour:

Some months ago ... we had occasion to speak in rather uncomplimentary terms of Mr. Talbot's Greece and the Greeks. We regret that we cannot make amends by praising the present work. It is true that his version of the Enchiridion does not contain the same mass of mistakes or display such astonishing general ignorance as his previous publication, but the improvement in this respect seems to be due to an increase of caution rather than to any advance in knowledge. Various passages in Greece and the Greeks pointed to the conclusion that Mr. Talbot, to put it mildly, had no very accurate knowledge of the Greek, or, for the matter of that, of the Latin language. He has avoided giving further evidence of this unfortunate deficiency by taking care that his "translation" shall have as little as possible to do with the text of his author. 
After that it gets much worse, but there is no point in quoting any more. For all this reviewer's poison, it must be acknowledged that although unkind, he is accurate. The verdict must be that these two books are the work of an enthusiastic, well-meaning dilettante.

It is difficult to describe comprehensively the place that classical learning had in Newfoundland society (distinct from the educational system) in the nineteenth and early twentieth centuries. The writing and publication of Talbot's books represent unique events - attempts at what we today call "classical scholarship" - but other products or activities on a smaller scale can be found. Catholic clerics in particular used Latin as a medium of communication, of course..$^{65}$ The polymath Moses Harvey (1820-1901) published in The Maritime Monthly an article on the Roman catacombs and a two-part article on Pompeii. ${ }^{66}$ There is a report of a lecture delivered in the Athenaeum in 1877 by A.J.W. McNeilly, "When Astraea shall return' or the coming of the new golden age" ${ }^{67}$; the reference to Astraea is drawn from Virgil's Fourth Eclogue, the so-called "Messianic." ${ }^{68}$ In 1938 a writer in the Newfoundland Quarterly reports that around 1888 the same McNeilly published in one of the local papers (source and date unspecified) a send-up of Horace's Satire 9 in Book 1, called "Against Bores and Such," adapted to the contemporary Newfoundland scene. Only the beginning could be recalled:

Walking one day down 'sacred'Water Street

Musing on politics, I chanced to meet

A noted bore, one whom by name I knew,

Or just enough to pass with 'how dy'e do.'

He rushed upon me like a body-gripper

And grasped my passive hand within his flipper. ${ }^{69}$

In 1899 in the Tribune Holiday Number, a Christmas annual, Bishop Howley published a translation of Horace, Odes Book 3, 25 - remarkably so, since it is an invocation to the god Bacchus. ${ }^{70}$ And books on Greek and Roman history and culture, for general readers and not only 
for students, could be purchased from local sellers and borrowed from the collection in the Athenaeum, though after its destruction in the fire of 1892 St. John's did not have a public library again until $1936 .{ }^{71}$

All this does not amount to very much, ${ }^{72}$ but one source has proved to be a gauge of the classical presence in Newfoundland among people who cared about such things. The Nerwfoundland Quarterly $(N Q)$ is Canada's oldest operating magazine, designed at its inception in 1901 to be "a literary magazine of interest to Newfoundlanders at home and abroad." ${ }^{73}$ I have combed all 100 issues up to 1925 for relevant evidence. Of course, the very trivial does not deserve much notice, or else it has value only for its humour. For instance, we learn that Laurence O'Brien, representative for St. John's in the House of Assembly (1841-50), who succeeded in having many roads built in various outports near the city, was called "The Colossus of Roads," and, in an obvious play on words, an article on fly-fishing was authored by "Exocoetus Volitans," the Linnaean term for a species of tropical flying fish. ${ }^{74}$ Other casual references - to Caesar, Cicero, Seneca, Aeschylus, Euripides, Homer, Socrates, Quintilian, Josephus, and so on - do not tell us much, each on its own, ${ }^{75}$ but their sheer number and the facility with which they are usually incorporated into essays or, occasionally, poems say a good deal about the authors' level of comfort with classical antiquity. Consider one example, the sixth stanza in the eight-stanza poem Limericks, by Eros Wayback (a.k.a. Edward St. George) in NQ 6.1 (1906: 12). The subject of the stanza is a woman recently arrived in the Underworld:

Then she dropped with the shades down in Hades, As, "Facilis descensus" the grade is, The Chief said he'd be hanged, As well as being danged, If he'd keep open hall for such ladies.

Facilis descensus - "the descent is easy," but here with the meaning "an easy descent" - is drawn from Virgil's Aeneid Book 6, line 126. The 
fuller context includes lines 128-29: Tros Anchisiade, facilis descensus Averno ... sed revocare gradum superasque evadere ad auras, / hoc opus, hic labor est. - "Trojan, son of Anchises, the descent by Avernus is easy ... but to retrace your step, and to escape to the upper breezes, this is the task, this is the hard work." It is, admittedly, one of Virgil's most famous passages. But that is the point: the author is not parading his learning so much as giving his audience a good chance to identify the allusion, and incongruity is then registered through the transposition from Latin epic to a vastly more humble form of poetic expression. The hallmark of the limerick — when not obscenity — is verbal invention, and the insertion of a short, familiar Virgilian phrase puts that quality on display.

Some classical references are perhaps less successful but of considerable interest nonetheless. One of these is from Rev. M.F. Power, "Where and whereby the Mic Mac dwells" (NQ 10.1 [1910: 16]). Without naming his source, Power opens with a purple summary of the dramatic setting of Plato's dialogue Phaedrus, which involves the characters Socrates and his younger friend Phaedrus:

The wise man of Stagira, ${ }^{76}$ under cover of a luxuriant plane-tree, which sheltered the flow of classic Ilissus, experienced a celestial impression and deified the genius of that lovely Grecian spot. Like all noble souls in which reside the re-echoes of eternal melody, his was enraptured with the divine attractiveness and poetic charm of rural scenery. The glowing picture he had created of the city's superiority was blurred indeed, when sojourning in the country he beheld Nature's garden of delights. In Bay d'Espoir the visitor undoubtedly feels the Socratic inspiration, and becomes imbued with that divine afflatus, generated of the lovely and the beautiful.

The setting of Plato's Phaedrus is among the most prominent and influential expressions of the ancient literary locus amoenus, that is, the ideal 
or mythic "beautiful place," evoked especially in pastoral poetry; in the Renaissance it becomes the site of the Golden Age. ${ }^{77}$ It is this feature that makes the Platonic dialogue attractive to Power and useful for one of the themes of his article, for the Mi'kmaq of Bay d'Espoir, who are here labelled "supremely happy," are also described by him as inhabiting "undiscovered country" containing "fields of the blessed." This is essentially the world that Parmenius, Peckham, Eburne, Hayman, and some others tried to sell to their English contemporaries 300 years earlier.

Our focus in these hundred issues of the Quarterly is on the appearance of Latin quotations, translations of passages from ancient Greek and Roman literature, and summaries of other specific ancient passages. The conservative tally, according to Appendix 2, comes to 18 different authors and nearly 50 different passages, mainly in Latin, sometimes in translation (especially the Greek passages), and including a few paraphrases. Even a cursory look at this index reveals the impressive dominance of the Roman poet Horace. Fully a third of the passages in question are from his works, and they are chiefly quotations in Latin, with a few references to specific passages as well. How to account for this attraction? At a general level we can say that Edwardian literate culture was comfortable with Latin quotation; this is, after all, a society in which an article in the Quarterly (7.2 [1907:19]) about the opening of the new Ayres furniture store in 1907 could end with the invocation esto perpetua, "may it be everlasting" (a stock phrase, to be sure). At a more specific level we should know that it is in the character of Horace's poetry to invite quotation, specifically because of its frequent expression of universal sentiments; Rudyard Kipling, exactly contemporary with this period, called him "the soundest Platitudinarian that ever was." ${ }^{\text {" Th }}$ This characterization is easy to illustrate from four especially famous and popular reflections, all from the third book of Horace's Odes, and all appearing in the Quarterly within a period of less than 15 years:

Odes Book 3, 1.1: odi profanum vulgus et arceo — "I hate the uninitiated mob and I keep them away" (NQ 6.1 [1907: 7]). 
Odes Book 3, 2.13: dulce et decorum est pro patria mori - "It is sweet and fitting to die for one's country" $(N Q 17.2$ [1918: 30]). ${ }^{79}$

Odes Book 3, 30.1: exegi monumentum aere perennius — "I have completed a monument more everlasting than bronze" (NQ 20.1 [1920: 23]).

Odes Book 3, 30.6: non omnis moriar — "I shall not die entirely" (NQ 20.1 [1920: 22]).

But more to the point, Horace's poetry, especially his Odes, was at this time a staple of the literary canon for students of Latin in the English-speaking world, as it was throughout Europe, and as it had been for centuries. Horace himself feared, presciently, that this would be the fate of his poetry. ${ }^{80}$ In Newfoundland, Books 1, 2, and 3 of Horace's Odes were each at different times standard fare for students of Latin. Writing in the Quarterly in 1912 of his business trips around the island, William Blackall, by now the inspector of Church of England schools, recounted that the reading material he would bring with him included an edition of Horace's Odes: he did not want his Latin to get "rusty," and he enjoyed what he called the "dainty bits" in Horace's poetry. ${ }^{81}$ The late first-century Roman Quintilian, himself a kind of "inspector of schools," had said much the same of Horace, that "he is full of pleasantness and charm" (Training in Oratory 10.1.96: plenus est iucunditatis et gratiae). In the nineteenth century and into the twentieth, Horace was "supremely, the gentleman poet" and "a kind of honorary Victorian." 82 The most recent similar response to Horace that I can find is from John Carey, now emeritus Merton Professor of English Literature at Oxford University. In his recent autobiography he writes about the affection he had for Horace and the attraction that the poet exercised upon him in formative years. In 1951 he was interviewed for undergraduate admission to Oxford by about 12 men and was asked whether he thought Horace or Virgil the greater poet: "I answered instantly, 'Oh, Horace,' and they all laughed, except one who seemed to be asleep." 83 
Of special interest are the purposes for which Horace's poetry is put to use. More than any other single context, it is in articles about angling, more specifically fly-fishing, of which there are many in the first 15 years or so of the Nerwfoundland Quarterly. It has always been one of the most popular recreations in Newfoundland and Labrador, and in the first decades of the twentieth century it was among the main activities put on display in the successful effort to draw American tourists. ${ }^{84}$ The special attraction exercised by quotation from and allusion to Horace in this context lies in his exquisite treatment and descriptions of nature. The evocation of nature is a commonplace in literature on angling, running from the Treatise of Fishing with an Angle, attributed to Dame Juliana Berners (second half of the fifteenth century) and Izaak Walton's Compleat Angler (1650s), through Thoreau and Hemingway, to Norman Maclean's A River Runs Through It (1976). ${ }^{85}$ In the Quarterly, there is a symbiosis between fly-fishing and nature - as one writer expresses it, "all good anglers are lovers of nature" 86 - and it is given further depth through the many black-andwhite photographs of the rivers, streams, and ponds that await the angler. These articles and the province's contemporary advertising campaign also paint a picture of an unspoiled land of serenity, a locus amoenus, in a Golden Age. This image has long been an element in perceptions of Newfoundland and in its people's assumptions about their land. We have already seen it in the works of the earliest writers about the island. It is apparent also in some of Newfoundland's place names - Paradise, Heart's Content, Heart's Delight, Placentia/Plaisance and Avalon come to mind at once - and it received an official, government imprimatur in the late 1960s with the application of the slogan "Canada's Happy Province" to all automobile licence plates ${ }^{87}$ The famous advertising campaign for the province's tourism industry, launched in 2006, relies on some similar conceptions of the place.

On 1 July 1916, at Beaumont Hamel on the first day of the Battle of the Somme, 272 of 790 members in the Newfoundland Regiment were killed and another 438 wounded. In the writing on Newfoundland's contribution to the Great War, one expects that line 13 of 
Horace, Odes Book 3, 2 would make an appearance somewhere in the Quarterly: dulce et decorum est pro patria mori, "It is sweet and fitting to die for one's country."These may be Horace's most famous words, and they are quoted constantly and everywhere during the war and for some years after. And the line does appear, as we shall see; but well before then, about six months after the catastrophe of 1 July, it is Horace's ultimate model, the late seventh-century BC Spartan poet, Tyrtaeus, who is quoted (fragment 10, lines 27-30), in the anonymous article "Our Heroic Dead" (16.3 [1916: 5]):

Our soldier heroes who die in blooming years, In man's regret will live and women's tears;

More sacred than in life, and lovelier far,

For having perished in the front at war.

There is poignancy in placing those lines beside a sentence from a letter by the American poet Alan Seeger to his mother, which was reproduced in the fall issue of 1917 (17.2: 30): "If I should not [return], you must be proud, like a Spartan mother, and feel that it is your contribution to the triumph of the cause whose righteousness you feel so keenly." ${ }^{88}$ When Horace's line is used, it is at the moment that the war is ending, in an article entitled simply "Loyalty" (18.2 [1918: 12]). The author of that article is no Newfoundland version of the famously malignant Professor Kantorek in the 1930 film production of Erich Maria Remarque's novel, All Quiet on the Western Front, who utters the line before all the carnage takes place (a role more prominent in the film than in the novel), ${ }^{89}$ but rather a young woman named Catherine Harris, writing after it..$^{90}$ Both Kantorek and Harris use the line for a rhetorical crescendo, Kantorek with terrible irony, Harris without a trace. Some may be surprised by that lack of irony (and perhaps by the sex of the person using the line in the Quarterly), but unlike in Britain, Canada and Australia, no anti-war literature seems to have been produced in Newfoundland in the last years of World War I or in the twenties, and no anti-war sentiment seems to have been expressed in the Quarterly. ${ }^{91}$ 
Classical quotation and allusion dry up almost entirely in the Quarterly between the end of the Great War and 1925. The two notable exceptions occur in the addresses given by the island's Governor, Sir Charles Alexander Harris, at the ceremonies held in 1920 and 1922 in Bannerman Park to commemorate the war dead. In the first of those years he quoted Horace twice, both from the third book of the Odes, poem 30: exegi monumentum aere perennius, and non omnis moriar multaque pars mei / vitabit Libitinam (lines 1, 6-7; see above). In the second address, he made extensive reference to Pericles' Funeral Speech in Thucydides' History (Book 2, 35-46). ${ }^{92}$ Notwithstanding the aversion to anti-war writing in Newfoundland, I wonder whether this apparent rejection of classical models is to be connected with the disillusionment caused by the war and consequent disdain for the culture with which it was associated - an outlook that precipitated also the discontinuation of compulsory Greek at Oxford and Cambridge in 1919 (see above). ${ }^{93}$ We see the disillusionment, if not cynicism, in, for instance, the poetry of Wilfred Owen and Siegfried Sassoon, and it is brought out powerfully in All Quiet on the Western Front, the greatest of all anti-war films.

\section{Conclusion}

Classical learning had a presence in many of the signal moments and lines of development in the history of Newfoundland: in its settlement and frustrated attempts at settlement, and in the stated justifications for these attempts; in the education of its people, from the humble beginnings of the first schoolhouse, throughout the period of largescale colonization, up to the founding of Memorial University College; in confirming unbreakable historical and cultural bonds with the mother country; in connecting the island culturally with the larger Western world and its foundations and norms; in endowing its built environment with an aura of stability, security, and prosperity; in helping to give expression to the beauty of the place, sometimes in nearmythic terms, and to convey a sense of belonging; and in confronting 
Newfoundland's most tragic losses. Readers will have no trouble identifying the most prominent recurring themes in this classical presence: the "Golden Age" and its freedom from toil, the locus amoenus or "(mythically) beautiful place," and the wondrous land at the end of a momentous voyage of discovery. The emergence of these themes, however, should not obscure the fact that the story is by no means a simple one.

Some other evidence for classical learning is known and could have been presented. ${ }^{94}$ No doubt more exists that is unknown; perhaps some of it would be significant. But the former would not change the picture presented here, and we can be confident that the latter would modify it only on the margins, if at all.

\section{Appendix 1: Richard Eburne's Quotations and References}

Cicero, On Duties 1.61 (citing Ennius), 1.7.21; Tusculan Disputations 5.108 (citing Pacuvius); In Defence of Flaccus 12

Horace, Epistle 1, 11.27; The Art of Poetry 72

Ovid, The Art of Love 2.13, 3.63, 426; Fasti 1.493-94

Elder Pliny, Natural History 12.5.3, 35.85

Erasmus, Adagia (2x)

Livy, History of Rome 1.1

Plutarch, Life of Cleomenes 38

Publilius Syrus, Sayings (Sententiae)

Tacitus, Annals 2.26

Terence, Brothers 45, Andria 74

Virgil, Eclogues 7.24

\section{Appendix 2: Latin and Greek Quotations and Allusions in the Newfoundland Quarterly, 1901-1925}

Aeschylus, Persians 808-29; Agamemnon 763-66

Caesar, Gallic War 6.21-28

Cicero, On the Nature of the Gods 3.40 
Homer (poluphloisboio thalasses, "loud-sounding sea"; glaukopis, "brighteyed")

Horace, Odes Book 1, 3.12-14, 7.31, 11.8, 24.1, 34.1; Odes Book 3, 1.1, 2.13, 13, 30.1, 6-7; Epistle 1, 10.24-25; The Art of Poetry 5; Epode 2.1; Satires Book 1, 1.95, 3.1; cf. Odes Book 1, 1.19, Book 2, 7.21, Book 3, 13.2

Juvenal, Satires 7.52, 10.356

Lucretius, The Nature of the Universe 4.1133

Ovid, Metamorphoses Book 1, 7; Heroides 2.85

Pindar, Olympian Ode 2, 61-73

Plato, Phaedrus 227a-229b, Republic 344c, 501b

Pliny, Epistles Book 6, 16 and 20

Plutarch, Moralia 228e (Spartan Sayings 28); Life of Phocion 36.3

Seneca, Medea 378 (with allusion to 375-79)

Sophocles, Antigone 611-13

Tacitus, Annals Book 3, 76; Germania 36

Tyrtaeus 10.27-30 West

Velleius Paterculus 2.118.1 (2x) (Germania mendax)

Virgil, Aeneid Book 1, 277-79, 283-88, 291-96, Book 6, 126; Eclogues 1.1, 7.4; Georgics Book 2, 458

\section{Appendix 3: G.R. Parkin, "The Study of Greek" [annotation in pencil: "Sent to Churchmen"] (see n. 58 above)}

While travelling through the United States during the last two years in connection with the organization of the Rhodes Scholarship scheme I have constantly been made aware of the slight importance given to the study of Greek at many centres of American education. Even the small quantity of Greek required to pass the Responsions examination at Oxford, which is the only qualifying test applied to candidates for the Scholarship, has proved a stumbling block to great numbers of those who have aspired to become Rhodes Scholars. It has often been suggested [superscript addendum in pencil: "to me"] that the tide is now setting so strongly in the United States against the study of Greek 
as an unpractical and comparatively useless subject that our chance of getting the ablest young Americans as competitors for the Scholarship would be greatly improved if we could induce Oxford to relax regulations which now make Greek a compulsory study for the ordinary undergraduate up to the time when he has passed the first public examination.

[For further discussion about the obstacle that the Greek requirement presented to American candidates for the Rhodes Scholarship, see Alexander (2001: 114-115).]

\section{Acknowledgements}

An earlier version of this paper was delivered as a public lecture at the annual conference of the Classical Association of Canada, held in St. John's in May 2017. For advice on specific questions and for much information besides, I am grateful to Ms. Colleen Field, Centre for Newfoundland Studies, Memorial University of Newfoundland; Dr. Ágnes Juhász-Ormsby, Department of English, MUN; Dr. Bernie Kavanagh, Department of Classics, Queen's University; Dr. Denyse Lynde, Department of English, MUN; and the staff of the Newfoundland and Labrador Provincial Archives. I also received much help and encouragement from the editor of Nerwfoundland and Labrador Studies, Dr. James Feehan, and from the journal's three anonymous readers. None of them, however, is responsible for any errors.

\section{Notes}

1 See the works cited in Joyal (2001: 4-5 n. 7).

2 In this paper I define "classical learning" broadly (as will become apparent), but my emphasis is especially on the languages and literature of the ancient Greeks and Romans and the uses to which they were put. One fruitful source of evidence with which I do not deal is the collection of Latin inscriptions found especially in the cemeteries of St. John's. These form the topic of an article Bernie Kavanagh is preparing for publication. 
4 See Brand (1940).

5 On the place of Latin in colonial Mexico and Latin America, and in New France, see (respectively) Laird (2015) and Cottier and Westra (2015); also Ijsewijn (1990: 284-310).

6 The year 1925 is a suitable place to end this story, not simply because the locus for the study of ancient Greeks and Romans shifts at that time, but especially because a history of Memorial University's Department of Classics, 1925-2000, has already appeared (Joyal, 2001). Moreover, this terminus marks an event whose facts reach back even further than the 350-year period we will be covering. In the fall of 1926, John Lewis Paton announced the adoption of MUC's motto, Provehito in Altum, "Launch forth into the deep." His source was Luke 5:4; but as Richard Pollard has recently demonstrated, the Latin comes not from St. Jerome's Vulgate Bible, as one would naturally expect, but rather from the translation of the New Testament by Theodore Beza, Professor of Greek at Lausanne for a few years after 1549 and at Geneva from 1558, enemy of the Catholic Church, and ally of John Calvin. What is more, Pollard has made it likely that Paton looked to this Latin source for quite personal reasons when he adopted the motto for the College; see Pollard (2014); and for Paton as classical scholar, see Huxley (2001).

7 Basic to the study of Parmenius's writings and what little is known of his life is Quinn and Cheshire (1972), which includes all of his known works plus an introduction and commentary; see also Quinn (1990).

8 Possibly polar bears, but Parmenius's description does not allow certainty (Quinn and Cheshire, 1972: 168-169, 182, Letter from Newfoundland, 40-41): "Bears sometimes appear around the shelters and are killed; but they are white, as far as I have been able to surmise from their skins, and they are smaller than ours" (ursi circa tiguria nonnumquam apparent et conficiuntur; sed albi sunt, ut mibi ex pellibus coniicere licuit, et minores quam nostri). It is not clear from these words that Parmenius even saw a live bear. Today the occasional appearance of a polar bear near St. John's, made possible by transport on pack ice, is never a casual event. All translations of Latin and Greek are my own, unless indicated otherwise. 


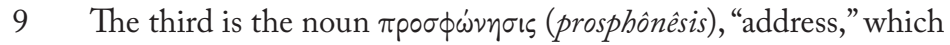
appears in the poetic dedication to Henry Unton prefacing Parmenius's Paean; see Quinn and Cheshire (1972: 142, 157).

10 The words are physêtêr (line 21), literally "blower" (i.e., a whale), and Oenotriae (line 261), a learned surrogate for "Rome"; see Quinn and Cheshire (1972: 25 and n. 8, 111, 134).

11 One of the journal's readers suggests that the tenth-century Latin Voyage of St. Brendan (Navigatio Sancti Brendani), in which St.

Brendan (c. 489-c. 577) and his company sail to a paradisiacal Island of the Blessed, may also have been a literary source for Parmenius. I have not identified clear points of contact between these two works, but the question may deserve a more intensive philological examination than I have given it. Nevertheless, Bishop M.F. Howley's reading of the Navigatio led him to accept (as a few others have done) that St. Brendan visited Newfoundland (1888: 38-40; cf. Nerwfoundland Quarterly 1.3 [1901: 4]), and Bishop Mullock (1860: 5) viewed the story as a traditional reflection of fact. For brief overviews of the evidence, see Brown (1993: 245-246); Macpherson (1997: 16-18).

12 For Renaissance interest in and use of Greek and Roman sources for the "Golden Age," see Levin (1969: esp. 58-83); and for observations on Parmenius's linking of this "ideal time" with an "ideal place" (locus amoenus, literally "beautiful place"), see Barnett (1997) (though Parmenius's eyewitness description in his letter to Hakluyt presents a very different image). By his use of the noun vates, literally "seer" (lines 67, 165), Parmenius indicates implicitly that he is drawing on these ancient poets. Obsolescent and viewed as archaic by the time of Virgil, Ovid, and Horace, vates was revived during the principate of Augustus (27 BC-AD 14) as an elevated term for the "divinely inspired poet." For its use in Renaissance literature, see Giamatti (1968: 445-452).

13 See Quinn and Cheshire (1972: 24-25, 110, 111-113, 117-118, 121-122, 124-125, 127-128).

14 Merely for illustration, I cite two examples in the poem's first two and a half lines: Quae nova tam subito mutati gratia coeli? / Unde graves nimbi vitreas tenuantur in auras, / Diffugiunt nebulae ... . / "What is this unexpected favour of a sky that has so suddenly changed? The fogs are scattering from the place where the heavy clouds dissolve into light 
breezes ...." For "a sky that has changed" (mutati ... coeli) in line 1, cf. Horace, Epistles Book 1.11, line 27: caelum, non animum mutant, qui trans mare currunt, "The sky, not their spirit, do they change who cross the sea" - a famous line of obvious potential application to transatlantic exploration (used in just such a context by Richard Eburne; see Appendix 1). For "the fogs are scattering" (diffugiunt nebulae) in line 3, cf. Horace, Odes Book 4.7, line 1 (the poem's opening words): diffugere nives, "the snows have scattered."Always one of Horace's most celebrated poems, it was, for instance, given a musical setting in Germany at the end of the fifteenth century (Petrus Tritonius) and in England in the middle of the seventeenth (John Wilson); later, it was judged by A.E. Housman to be "the most beautiful poem in ancient literature" (Brink, 1985: 162-163) and was similarly esteemed by Housman's contemporary Rudyard Kipling (Treggiari, 1985: 425-426).

15 Early in the first chapter of Peckham's work, 446-447 in Quinn's edition (1940). For discussion of the arguments Peckham uses in this treatise, see Williams (1990: 165-172).

16 For more expansive accounts, with important detail and analysis, see Cell (1969: 53-96); Pope (2004: 47-59).

17 Calvert himself appears to have been a competent Latinist; see Smith (1931), a speculative article, but it includes (114-116) the text and translation of Calvert's little-known 12-line funeral poem Carmen funebre in D. Hen. Untonum (1596). For its themes, including that of the "Golden Age" (pristina aetas), Calvert relied heavily on Ovid's Metamorphoses, but for its meter (Alcmanic strophe) he drew upon Horace. For the poem's dedicatee, Henry Unton, see above, n. 9.

18 Not the least of them was the Newfoundland winter; so, for instance, Calvert in a letter in 1629 to King Charles I (see Cell [1982: 295296]). Most advocates for settlement felt compelled to address the issue; Richard Whitbourne, for example, in A Discourse and Discovery of New-Foundland, affirmed that the weather on the island was not nearly as atrocious as its reputation (see Cell's edition of Whitbourne's work [1982: 152-156]).

19 For indirect support of Eburne's use of Plato, compare the application 25 years earlier of a much less-read Platonic work (the Alcibiades I) by a much better-known writer (Shakespeare, in Julius Caesar); see Alvis 
(1979). Shakespeare would have relied on one of the Latin translations cited here.

20 Eburne's references are in Wright's edition (1962: 42, in the larger context of 32-42). For Hawkins's poem, see Quinn (1940: 438-439); and for a list and summary of the many works in which similar arguments are made, see Rogers (1931: 32-35). Sparseness of population or wilderness contributes to the presentation of Newfoundland as locus amoenus (see above, n. 12), as it would continue to do in the promotion of tourism in the late nineteenth and early twentieth centuries (see below, at nn. 84-87; Pocius [1994: 60-66]).

21 Greek mythology does not provide a clear source for this view of the Trojan War; at best there is the tradition that Zeus (supreme god of the Greeks) contrived the war's causes in order to reduce the world's population. For ancient sources and knowledge of them in the sixteenth century, see Reeves (1966). The fifth-century historian Thucydides, however, saw the war as a conflict less of revenge and punishment (over the abduction of Helen) than of conquest and acquisition (Book 1,8-9). This may be the tradition on which Hawkins ultimately relied.

22 See Wright (1962: 99).

23 On Vaughan, see Cell (1965b).

24 For a more sympathetic account of Vaughan's work, see Fitzmaurice (2007: 224-227).

25 See Cell (1982: 25 n. 4), who excludes The Golden Fleece from her collection of seventeenth-century texts on the exploration of Newfoundland on the grounds that "so little of it deals directly with Newfoundland, and because it makes no contribution to geographical knowledge of the island."

26 In Greek mythology, Orpheus was a musician of supernatural talent, able (for example) to charm even rocks and trees into following him. Apollo is associated in Greek thought with (among other things) rationality and civilized pursuits, including music. The relationship between Orpheus and Apollo is a close one, and both play a role in Jason's quest for the Golden Fleece. Colchos (or Colchis; modern Georgia) was a barbarian (i.e., non-Greek) kingdom on the eastern coast of the Black Sea where Jason ventured to retrieve the Fleece. 
27 On Hayman, see Cell (1965a).

28 The comparison Hayman makes here on the basis of Socrates' ugly exterior but precious interior originated in Plato, Symposium 215a-216c. Other poems in Quodlibets that draw upon or include reference to classical characters or themes are Book 1.4, 43, 109, 111, 114; Book 2.42, 95; Book 3.22, 35, 46, 82, 83, 86, 89, 99; Book 4.10.

29 Compare also Quodlibets, Book 2.79-81, 86-88. The theme appears as well in the poems by Richard Bingham and Martin Frobisher that introduce Sir George Peckham's treatise; see Quinn (1940: 439-440).

30 See Jones (1941); Doelman (2016: 21-22, in the larger context of 15-44).

31 There are some useful remarks in Doelman (2016); see his index, s.v. Hayman, Robert (396).

32 Contemporary with Hayman was the remarkable George Sandys, who translated Ovid's Metamorphoses on his voyage to the Jamestown colony and during his residence there (1621-25); see Davis (1955: 198-226). The earliest of the Latin (prose) Jesuit Relations (1612) predates Sandys and Hayman by a few years; see Cottier and Westra (2015: 542).

33 The earliest (brief) assessment of Hayman's verse I have found is in MacDonald (1938: 17-18). MacDonald describes it as "sorry stuff, little better than doggerel, and with a good deal of coarseness and vulgarity in thought and expression." Cell takes notice of all Hayman's original literary activities but none of his translations of Owen (1982: 18-19). In the list of translations of Owen's epigrams that he provides in the Introduction to his helpful commentary on those poems, Dana Ferrin Sutton does not include Hayman's translations, though they are earlier than all others cited but one; see http://www.philological.bham. ac.uk/owen/contents.html. I am grateful to Professor Sutton for correspondence about Owen, Hayman, and Sandys.

34 Rollmann and Power (1989). Fizzard's article (1995) adds little to that earlier study and, indeed, takes no account of it. See also Billard (2000: 21-24).

35 See Rollmann and Power (1989: 30). For the popularity of this book in contemporary America, see Beales and Monaghan (2007: 384-385).

36 See also Monaghan (2005: 216-231). 
37 For details, see Joyal, McDougall, and Yardley (2009: 124-127, 170-174, 195-197); also Marrou (1956: 150-157, 269-271).

38 See Marrou (1956: 330-331); Black (2001: 36-38); Reynolds (1996: 7-11, 17-28, 88-96).

39 No teacher is likely to have recognized the connection either. In fact, as far as I have been able to ascertain, the close similarities between ancient methods of teaching literacy and literature and those of the seventeenth and eighteenth centuries, to say nothing of their genetic relationship, have not been observed.

40 Contrast the expedient to which the author of The New England Primer resorted when faced with the same challenge: "eXhort one another daily" (Ford, 1899: 52). The New England Primer was the most widely used instructional method in America from the seventeenth to the early nineteenth centuries; see Monaghan (2005: 98-104).

41 For the character of the Distichs of Cato and their use in ancient Roman education, see Bloomer (2011: 139-169); for their transmission in Old English literature, see Hollis and Wright (1992: 15-33); and for their appearance in the Renaissance and after, see Ludwig (2011).

42 Latin and Greek were studied also in Queen's College, the Church of England theological seminary founded in St. John's in 1841. Of the over 2,500 books that Bishop Mullock donated to form the library of St. Bonaventure's College (opened in 1858, initially as a Catholic seminary), nearly a thousand were Latin texts and over a hundred were Greek, including a complete run of the Patrologia Latina and about two-thirds of the Patrologia Graeca, published in Paris by Jacques-Paul Migne between 1844 and 1867; see Juhász-Ormsby (2016: 27-30); Schipper (2016).

43 See Rowe (1952: 58-59; 1964: 60).

44 For the teaching of Greek and Latin in the Harbour Grace Grammar School and the Carbonear Grammar School, see McCann (2016: 101-126, esp. 106-111, 114-116); and in the (short-lived, 1845-50) St. John's Academy, see McCann (2016: 237-261, esp. 240, 248-249, 261).

45 For Charles Durnford Newman, see McCann (2016: 249); for Maclaurin, see Rollmann (2016: 84-85); also the issue of The Adelphian 
(magazine of St. Bonaventure's College) published to mark the fiftieth anniversary of St. Bonaventure's (4.1 [1907: passim]). It was from Maclaurin's gift that Bishop Mullock added to his impressive library a copy of Richard Bentley's celebrated edition of Horace (second edition, 1713); see Nichol (2016: 92).

46 Sources for Maude Joyner include the Annual Report of the Department of Education, Nerwfoundland, 1921-1922 (St. John's, 1923), 30; The Feildian [magazine of Bishop Feild College] 27.2 (1921: 71), where her alma mater is mistakenly given as the University of Aberdeen; and the St Andrews Citizen, 19 Mar., 23 Apr. 1910.

47 For Burnet, see Joyal (2004); for Lindsay, see Rose (1937) and Deufert (2004).

48 Translation: The (female) principal of the College and (female) students, standing on the shore, await the arrival of the school-mistresses who are coming from England. / First student: What a thick fog sits on the sea. / Second student: The teachers from Britain will get a bad opinion of our island. / First student: What bad luck! / Principal: The ship hasn't arrived yet; let's pray that the weather may improve. / Third student: Look! It's raining! / Second student: Good heavens, it is!

49 She departed in 1923 to take up "a very fine position" at Bishop Strachan School in Toronto (The Feildian 28.4 [1922-23: 117]). Her replacement was S.S. Horseley, who held an MA in Classics from Merton College, Oxford (The Feildian 28.4 [1922-23: 119]).

50 Stead, who died in the sinking of the Titanic, was in his time one of England's most important and controversial journalists and editors; see Baylen 2010.

51 In general on Parkin, see Christian (2008, esp. 204-253) for his work with the Rhodes Scholarship Trust.

52 Blackall was wrong about Rhodes's intention. At the start, one scholarship was allocated to Newfoundland, two to Canada. Today, 11 are allocated to Canada, including the one reserved for Newfoundland.

53 For Holloway, see Gough (2016) (brief reference to the Rhodes Scholarship at 185).

54 "Responsions" were the basic entrance examination for Oxford University, which "consisted of an elementary test in Greek, Latin, and mathematics. The Rhodes examination was modelled on it” (Kenny, 2001: 5 n. 17). 
55 See The Adelphian 1.3 (1904: 145). Alone among Newfoundland's students in 1904, Rhodes candidates from St. Bonaventure's were exempted from Responsions; see Newfoundland Quarterly 4.2 (1904: 21). The pressure under which Herbert had to reach the required competence in Greek was by no means unique; see The Adelphian 2.1 (1905: 45-46).

56 See Joyal (2001: 35-38).

57 The discontinuation of compulsory Greek at Oxford (and Cambridge) in 1919 is in itself a long and intricate story; see Stray (1998: 164-168, 265-270); Raphaely (1999).

58 G.R. Parkin Papers, Library and Archives Canada (LAC), MG 30, D44, Vol. 67 (File: Education, General [2]). I am grateful to LAC for providing me with a digital reproduction of this unpublished essay. Its first paragraph is presented in Appendix 3 below; it can now be read in its entirety on David Meadows's site "Rogue Classicism” (18 July 2017: https://rogueclassicism.com/2017/07/page/3/). For a broader narrative on the events and controversies in Newfoundland identified above, see McCalla (2001: 208-220; also 203-213 for Parkin's activities in Canada).

59 For details and explanations, see Joyal (2001: 25-26). My late departmental colleague at MUN, Iain Bruce (1937-2007), would tell an anecdote that nicely captures the dire situation. At in-person course registration in fall 1969, conducted in the university's old Thompson Student Centre (decades before online registration!) and staffed by faculty who tracked enrolment in their departments' courses, Leslie Harris, who was then Dean of Arts (later to become President of Memorial University, 1981-90), examined the enrolment data for the Beginner's Latin course and remarked to Iain, "It looks like the dead languages really are dead!"Yet, as desperate as the situation may have appeared at that time, thousands of students have studied Latin at MUN in the 50 years that followed.

60 Talbot (1882: 58, cf. 3-6).

61 See Whiteway (1970-71: 542-549).

62 Photographs of and discussion about each of these buildings can be found on the Newfoundland and Labrador Heritage Website: http:// www.heritage.nf.ca/index.php. 
63 The classical authors whose works he translates in the third book (Talbot, 1879) are Tyrtaeus, Theognis, pseudo-Phocylides, Solon, Simonides, and Horace (the only Latin author). Without exception the works in question or parts thereof are highly didactic or moralizing in subject matter and form. Hence Talbot cuts short his translation of Horace, Satire 2, on the following grounds: "Horace is so indecent in parts of his works as to forbid his being translated" (1879: 163).

64 Greece and the Greeks in The Saturday Review 51 (1881:25-26), the Enchiridion of Epictetus in 52 (1881: 553-554). The brief review of the latter book in The Spectator (18 Nov. 1882) is less acerbic but no more positive.

65 Some examples (all c. 1800) are in Howley (1888: 196-197, 200-201, 207).

66 "The Catacombs of Rome," The Maritime Montbly: A Magazine of Literature, Science and Art 1.4 (1873: 310-323); "Pompeii, pt. 1: The story of the doomed city," and "Pompeii, pt. 2: The excavated 'City of the Dead'," The Maritime Monthly 3.1 and 3.2 (1874) 32-47 and 108-123 (they are derivative essays, not dependent on original research). By the time that the two-part article was published, Pompeii had established a secure place in the North American literary imagination (inspired by Edward Bulwer-Lytton's 1834 novel, The Last Days of Pompeii); see Reinhold (1984: 265-276). For biographical details about Harvey, see Aldrich (1994).

67 Harbour Grace Standard 18, 14 (10 March 1877), 3 (“a very learned and eloquent Lecture").

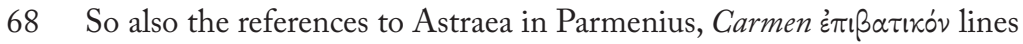
93-95, and Hayman, Quodlibets Book 3.22.

69 See MacDonald (1938: 20); and on McNeilly, see Story (1998). For comparison, here is Niall Rudd's translation of these lines in Penguin's The Satires of Horace and Persius (1973): "I happened to be strolling down Sacred Way, trying out / some piece of nonsense as I often do and completely absorbed in it, / when suddenly a fellow whom I knew only by name dashed up / and seized me by the hand." I have not attempted to track down McNeilly's entire translation in its original source.

70 It is tempting to suppose that Howley was attracted to Horace's poem at this time in the religious calendar on account of the persistent 
association in contemporary culture between the iconography of Bacchus/Dionysus and that of St. Nicholas (though the association was by then weakening considerably). The connection of course goes deeper than iconography; see, e.g., Siefker (1997: 48-63).

71 See Barker (2010: 30, 32-33); also Whiteway (1970-71: 546). Relatively few of the approximately 4,400 volumes in the Athenaeum's library in 1876 were on Greek and Roman subjects (see the Catalogue of Books in the Athenaeum Library). Most of these are historical studies, including the classic multi-volume works by Edward Gibbon (The Decline and Fall of the Roman Empire), George Grote (History of Greece), Charles Merivale (History of the Romans under the Empire), and Connop Thirlwall (History of Greece). The only ancient literature listed includes Homeric Ballads (i.e., mainly selections from the Odyssey) and Comedies of Lucian, Plutarch's Lives, and Thomas Moore's The Odes of Anacreon (i.e., the Anacreontea or "pseudo-Anacreon"), whose occasional homo-erotic themes could have run afoul of the Athenaeum's Constitution, which excluded "All books of an immoral character" (Catalogue, iv). There was also, unsurprisingly, a copy of Bulwer-Lytton's The Last Days of Pompeii (see above, n. 66). I am grateful to Colleen Field of MUN's Centre for Newfoundland Studies, who made available to me a digital copy of the Athenaeum's Catalogue. For Greek and Latin texts in the Episcopal Library of St. Bonaventure's College, see above, n. 42.

72 To the best of my knowledge - which is incomplete - no Greek or Roman tragedy or comedy, or portion thereof, was produced on the Newfoundland stage up to 1925 . Denyse Lynde informs me that in her research on the history of theatre in Newfoundland she has not encountered evidence for such a production. I have consulted all available digital copies of pre-1926 issues of The Feildian, The Spencerian, The Adelphian and The Collegian (on which see above) which are on the site of the Centre for Newfoundland Studies without encountering any record of a classical production in their associated schools. I am grateful to Colleen Field of the CNS for the many potential leads which she provided me in this search.

73 For a brief account of the Quarterly's first 85 years and its place in Newfoundland's literary culture, see Janes (1985); also Cuff (1993). 
74 D.W. Prowse, "The history of road-making in Newfoundland," NQ 2.4 (1903: 19); Exocoetus Volitans, "Fly-fishing in Newfoundland," NQ 3.3 (1903: 18). In his biography of Sir Cavendish Boyle, governor of Newfoundland 1901-1904, Graham (1979: 153) attributes to him an article on fly-fishing published in the Quarterly in 1903. Since the only article on fly-fishing to appear in 1903 is the one cited here, it appears that Exocoetus Volitans was Boyle himself. He was both an angler and a hunter, and may well have been familiar with this flying fish in his birthplace of Barbados, where it is native (as it is in the Caribbean generally). I thank Colleen Field for drawing my attention to relevant details in Graham's book.

75 The sole reference to Seneca (c. 4 BC-AD 65) deserves to be singled out. It appears in the first of Bishop Howley's many articles on Newfoundland place names ("Newfoundland name-lore," NQ 1.2 [1901: 2]); here he alludes to a prophecy of geographical discovery through the phrase novos orbes, "new worlds," in Seneca's tragedy Medea (lines 375-79). This Senecan passage has been the locus classicus for ancient predictions of New World exploration ever since its initial application by Christopher Columbus. Its use for this purpose relies on the false substitution in line 378 of the name Tiphys (the legendary helmsman of Jason's ship Argo), as the one who "uncovers" (detegat) new worlds, for the true reading Tethys (mythical consort of the god Oceanus); for a full account of the tradition behind the use of this passage, see Romm (1993: esp. 81-90); also Clay (1992); Brown (1993: 237-238). True to this tradition, Howley likewise reads Tiphys here instead of Tethys, and he does so also in his fuller discussion of this passage (1888: 38, 288-289). Howley is unusual, however, in demonstrating a knowledge of the text of Medea beyond these few famous lines (1888: 288 n. 2 [lines 301-8, with Howley's English translation]); see Romm (1993: 84 n. 30).

76 Power's error: the sobriquet belongs to Aristotle (often simply "the Stagirite"), not Socrates.

77 See also n. 12 above. For Richard Eburne's possible use of the opening of the Phaedrus, see above, n. 19.

78 See Treggiari (2012: n. 39).

79 Kipling's point is well illustrated by Bishop Mullock's use of this line 
in his lecture on Newfoundland (1860: 3): it "is not alone the expression of the pagan moralist, it is the universal feeling of all people in ancient and modern times."

80 See Horace, Epistles 1, 20.17-18 (addressing his own book of poetry): "This too awaits you, to be overcome by stammering old age as you teach children the rudiments on the outskirts of towns."

81 "Untrodden paths of Newfoundland," NQ 11.4 (1912: 3). Kipling, similarly, claimed late in his life (Feb. 1934) to have always travelled with a text of Horace; see Tregiarri (2012: n. 39, referencing Pinney [2004: 253]: "I am up to my back-teeth for the moment in Horace with whom I always travel").

82 See Vance (1993: 199, 216), whose discussion provides wide-ranging content to these characterizations. An authoritative, brief appreciation of the influence of Horace up to the present day is Most (2010).

83 See Carey (2014: 67).

84 For the history of fly-fishing in Newfoundland, see Hustins (2010: 18-63); for its role in Newfoundland's early tourism industry, see Pocius (1994: esp. 57-59).

85 Quite apart from the use of Horace's poetry in this context, fly-fishing has long had its own verse literature; see Hills (1923: 191-221). The poem by the American James Russell Lowell (1819-91), “To Mr. John Bartlett, who had sent me a seven-pound trout," excerpted by A.J.W. McNeilly in "The Californian Rainbow Trout" (NQ 6.1 [1906: 7-8]), itself includes (line 44) an allusion to Horace, Odes Book 3, 13.2 ("May Horace send him Massic wine").

86 F.C. Berteau, “Some Labrador rivers," NQ 10.1 (1911: 14).

87 See also Pocius (1994: 47-50, 60-68). For the Romantic element in some Newfoundland literature around the middle of the twentieth century, see O'Flaherty (1979: 151-183).

88 Alan Seeger perished on 4 July 1916 in the Battle of the Somme. His nephew was folksinger Pete Seeger.

89 For Kantorek, see Winkler (2000: 182-191).

90 There is a photograph of Catherine Harris in NQ 18.3 (1918: 20). Henry Polk Lowenstein's poem, "The last words of Funston; or 'How delightful it is!'," printed a year earlier than Harris's piece (NQ 17.1 [1917: 23]), clearly draws inspiration from the same line in Horace. 
91 See Harding (2006: esp. 17-18).

92 Governor Harris received a First in Classics from Christ's College, Cambridge, in 1878. Did many in his audience recognize or understand his references to Thucydides? It seems doubtful to me, though Harris must have expected that they would. He may have been conditioned to think so by the publicity given to the Funeral Speech in England during the First World War, where London buses in 1915 (two years before Harris left London for Newfoundland) carried an ad containing the words of Thucydides' History, Book 2, 43.4; see Azoulay (2014: 214-215); Turner (1981: 187-189).

93 See Raphaely (1999: 90-93).

94 Above all, The Feildian, The Spencerian, The Adelphian, and The Collegian contain a great deal of further information about the people involved in the teaching and learning of Greek and Latin in the schools associated with these magazines, and about the conditions in which these languages and the ancient world in general were taught.

\section{Documents}

Catalogue of Books in the Athenaeum Library, to which are prefixed the Constitution and Bye-laws of the Institution. St. John's, 1876. Printed by the Morning Chronicle. http://collections.mun.ca/cdm/ref/collection/cns2/ id/70961.

Dixon, Henry. The English Instructor; or, The Art of Spelling Improved: Being a more Plain, Easy, and Regular Method of Teaching Young Children, than any extant. In two parts. London, 1736.

Eburne, Richard. A Plain Pathway to Plantations (1624), ed. L.B. Wright. Published for the Folger Shakespeare Library by Cornell University Press. Ithaca, NY, 1962.

Hayman, Robert. Quodlibets, lately come over from New Britaniola, Old Nerwfoundland. London, 1628. http://www.mun.ca/rels/hrollmann/ relsoc/texts/hayman.html.

Parmenius, Stephen: see Quinn and Cheshire (1972).

Peckham, Sir George. A true report of the late discoueries, and possession taken in the right of the Crowne of England of the Newfound lands, By that valiant and worthy Gentlemen, Sir Humfrey Gilbert, Knight (12 November 1583). 
In D.B. Quinn, The Voyages and Colonising Enterprises of Sir Humphrey Gilbert, vol. 2. The Hakluyt Society, series II, no. 84. London, 1940. 435-482.

Vaughan, Sir William. The Golden Fleece, Divided into three Parts . . Transported from Cambrioll Colchos, out of the Southermost Part of the Iland, commonly called the Newfoundland ... London, 1626. http://www.mun. $\mathrm{ca} / \mathrm{rels} / \mathrm{hrollmann} / \mathrm{relsoc} /$ texts/vaughan/contents.html.

Whitbourne, Richard. A Discourse and Discovery of New-Foundland-Land (1620). In G.T. Cell, Nerwfoundland Discovered: English Attempts at Colonisation, 1610-1630. The Hakluyt Society, series II, no. 160. London, 1982.

\section{References}

Aldrich, F.A. 1994. "Harvey, Moses." In R. Cook, ed., Dictionary of Canadian Biography, vol. 13. Toronto. 455-457.

Alexander, D. 2001. “The American Scholarships.” In A. Kenny, ed., The History of the Rhodes Trust, 1902-1999. Oxford. 100-202.

Alvis, J. 1979. "A probable Platonic allusion and its significance in Shakespeare's Julius Caesar." The Upstart Crow 2: 64-73.

Azoulay, V. 2014. Pericles of Athens, trans. J. Lloyd. Princeton, NJ/Oxford.

Barker, W. 2010. "Three steps towards a history of the book in Newfoundland." Papers of the Bibliographical Society of Canada 48.1: 21-48.

Barnett, R.J. 1997. "New World colonization and the De Navigatione of Stephen Parmenius.” Intertexts 1: 159-168.

Baylen, J.O. 2010. “Stead, William Thomas (1849-1912).” In Oxford Dictionary of National Biography. Oxford. http://www.oxforddnb.com. uml.idm.oclc.org/view/article/36258.

Beales, R.W., and E.J. Monaghan. 2007. "Literacy and schoolbooks.” In H. Amory and D.D. Hall, eds., A History of the Book in America: The Colonial Book in the Atlantic World, vol. 1. Chapel Hill, NC.

Billard, G. 2000. "Early Newfoundland schools and the curriculum." Nerfoundland Quarterly 9.3/4: 21-28.

Black, R. 2001. Humanism and Education in Medieval and Renaissance Italy: Tradition and Innovation in Latin Schools from the Twelfth to the Fifteenth Century. Cambridge. 
Bloomer, W.M. 2011. The School of Rome: Latin Studies and the Origins of Liberal Education. Berkeley/Los Angeles/London.

Brand, D.D. 1940. "Where is the oldest university in the New World?" New Mexico Anthropologist 4.4: 61-63.

Brink, C.O. 1985. English Classical Scholarship: Historical Reflections on Bentley, Porson and Housman. Cambridge/New York.

Brown, S.C. 1993. "Far other worlds and other seas: The context of claims for pre-Columbian European contact with North America." Nerwfoundland Studies 9: 235-259.

Carey. J. 2014. The Unexpected Professor: An Oxford Life in Books. London. Cell, G.T. 1965a. "Hayman, Robert." In G.W. Brown, ed., Dictionary of Canadian Biography, vol. 1. Toronto. 365-366.

. 1965b. "Vaughan, Sir William." In G.W. Brown, ed., Dictionary of Canadian Biography, vol. 1. Toronto. 654-657.

-1969. English Enterprise in Nerwfoundland, 1577-1660. Toronto/ Buffalo.

1982. Nerwfoundland Discovered: English Attempts at Colonisation, 1610-1630. The Hakluyt Society, series II, no. 160. London.

Christian, W. 2008. Parkin: Canada's Most Famous Forgotten Man. Toronto.

Clay, D. 1992. "Columbus' Senecan prophecy." American Journal of Philology 113: 617-620.

Cottier, J.-F., and H. Westra. 2015. "North America - Part I: New France." In S. Knight and S. Tilg, eds., The Oxford Handbook of Neo-Latin. Oxford/New York. 541-547.

Cuff, H.A. 1993. "Nerwfoundland Quarterly." In C.F. Poole and R.H. Cuff, eds., Encyclopedia of Nerwfoundland and Labrador, vol. 4. St. John's. 63-65.

Davis, R.B. 1955. George Sandys, Poet-Adventurer: A Study in Anglo-American Culture in the Seventeenth Century. London.

Deufert, M. 2004. “Wallace Martin Lindsay (1858-1937).” In R.B. Todd, ed., The Thoemmes Dictionary of British Classicists, 1500-1960. Bristol. 583-585.

Doelman, J. 2016. The Epigram in England, 1590-1640. Manchester.

Fitzmaurice, A. 2007. “American corruption.” In J.F. McDiarmid, ed., The Monarchical Republic of Early Modern England: Essays in Response to Patrick Collinson. Aldershot/Burlington, VT. 
Fizzard, G. 1995. “Newfoundland's first known school.” Nerwfoundland Studies 11: 179-198.

Ford, P.L., ed. 1899. The New-England Primer. A reprint of the earliest known edition, with many facsimiles and reproductions, and an historical introduction. New York.

Giamatti, A.B. 1968. "Proteus Unbound: Some versions of the sea-god in the Renaissance." In P. Demetz, T. Greene, and L. Nelson, Jr., eds., The Disciplines of Criticism: Essays in Literary Theory, Interpretation, and History. New Haven/London. 437-475.

Gough, R.L. 2014. Robert Edwards Holloway: Newfoundland Educator, Scientist, Photographer, 1874-1904. Montreal/Kingston.

Graham, F.W. 1979. "We Love Thee Nerwfoundland". Biography of Sir Cavendish Boyle, K.C.M.G., Governor of Newfoundland, 1901-1904. St. John's.

Harding, R.J. 2006. "Glorious Tragedy: Newfoundland's cultural memory of the attack at Beaumont Hamel, 1916-1925.” Nerwfoundland and Labrador Studies 21: 3-40.

Hills, J.W. 1923. A History of Fly Fishing for Trout. London. Hollis, S., and M. Wright. 1992. Old English Prose of Secular Learning.

Annotated Bibliographies of Old and Middle English Literature, vol. 4. Cambridge.

Howley, M.F. 1888. Ecclesiastical History of Newfoundland. Boston.

Hustins, D. 2010. Rivers of Dreams: The Evolution of Fly-Fishing and Conservation of Atlantic Salmon in Newfoundland and Labrador (17001949). St. John's.

Huxley, H.H. 2001. "The unique qualities of Dr. J.L.A. Paton, together with an assessment of his virtuosity in Greek and Latin verse composition.” In M. Joyal, ed., In Altum: Seventy-Five Years of Classical Studies in Nerwfoundland. St. John's. 39-54.

Ijsewijn, J. 1990. Companion to Neo-Latin Studies, Part 1: History and Diffusion of Neo-Latin Literature, 2nd ed. Supplementa Humanistica Lovaniensia 5. Leuven.

Janes, P. 1985. "An overview of the Newfoundland Quarterly." In H. Cuff et al., eds., The Newfoundland Quarterly: Its Evolution over an 85-year Period. St. John's. 17-23.

Jones, J.H. 1941. "John Owen, the epigrammatist." Greece and Rome 10: 65-73. 
Joyal, M. 2001. “Classics at Memorial, 1925-2000: A brief history.” In M. Joyal, ed., In Altum: Seventy-Five Years of Classical Studies in Nerwfoundland. St. John's. 3-38.

—. 2004. "John Burnet (1863-1928)." In R.B. Todd, ed., The Thoemmes Dictionary of British Classicists, 1500-1960. Bristol. 124-126.

_ I. McDougall, and J.C. Yardley. 2009. Greek and Roman Education: A Sourcebook. London/New York.

Juhász-Ormsby, A. 2016. “The Mullock collection.” In A. Juhász-Ormsby and N. Earle, eds., The Finest Room in the Colony: The Library of John Thomas Mullock. St. John's. 27-37.

and N. Earle, eds. 2016. The Finest Room in the Colony: The Library of John Thomas Mullock. St. John's.

Kenny, A. 2001. "The Rhodes Trust and its administration." In A. Kenny, ed., The History of the Rhodes Trust, 1902-1999. Oxford. 1-99.

Laird, A. 2015. "Colonial Spanish America and Brazil." In S. Knight and S. Tilg, eds., The Oxford Handbook of Neo-Latin. Oxford/New York. $525-540$.

Levin, H. 1969. The Myth of the Golden Age in the Renaissance. Bloomington, IN/London.

Ludwig, W. 2011. "Tradition and creativity: The Disticha Catonis and the Monosticha of Publilius Syrus as poetic models in early modern times." In P. Galand, G. Ruozzi, S. Verhulst, and J. Vignes, eds., Tradition et créativité dans les formes gnomiques en Italie et en Europe du Nord (XIVeXVIIe siècles): Etudes réunies. Latinitates, vol. 4. Turnhout. 273-293.

MacDonald, R.G. 1938. "Some poets of Newfoundland and their work, pt. 1.” Nerwfoundland Quarterly 37.4: 17-20.

Macpherson, A.G. 1997. "Pre-Columbian discoveries and exploration of North America.” In J.L. Allen, ed., North American Exploration, vol. 1. Lincoln, NE/London.

Marrou, H.I. 1956. A History of Education in Antiquity, trans. G. Lamb. Madison, WI.

McCalla, D. 2001. "The Rhodes Scholarships in Canada and Newfoundland." In A. Kenny, ed., The History of the Rhodes Trust, 1902-1999. Oxford. 203-250.

McCann, P. 2016. Island in the Empire: Education, Religion, and Social Life in Nerwfoundland, 1800-1855. Portugal Cove-St. Philip's, NL. 
Monaghan, E.J. 2005. Learning to Read and Write in Colonial America. Amherst, MA/Boston.

Most, G.W. 2010. "Horace.” In A. Grafton, G.W. Most, and S. Settis, eds., The Classical Tradition. Cambridge, MA. 454-460.

Mullock, J.T. 1860. Two Lectures on Newfoundland, delivered at St. Bonaventure's College, 25 Jan. and 1 Feb. 1860. New York.

Nichol, D.W. 2016. "Latin Classics: Horace and Persius." In A. Juhász-Ormsby and N. Earle, eds., The Finest Room in the Colony: The Library of John Thomas Mullock. St. John's. 92-93.

O'Flaherty, P. 1979. The Rock Observed: Studies in the Literature of Newfoundland. Toronto/Buffalo/London.

Pinney, T., ed. 2004. The Letters of Rudyard Kipling, vol. 6 (1931-36). Iowa City, IA.

Pocius, G.L. 1994. “Tourists, health seekers and sportsmen: Luring Americans to Newfoundland in the early twentieth century." In J. Hiller and P. Neary, eds., Twentieth-century Nerwfoundland: Explorations. Newfoundland History Series 7. St. John's. 47-77.

Pollard, R.M. 2014. "Provehito in Altum ('Launch out into the deep')." Newfoundland and Labrador Studies 29: 227-243.

Pope, P.E. 2004. Fish into Wine: The Nerwfoundland Plantation in the Seventeenth Century. Chapel Hill, NC/London.

Prowse, D.W. 1896. A History of Newfoundland, from the English, Colonial, and Foreign Records, 2nd ed. London.

Quinn, D.B. 1990. "Stephanus Parmenius Budaeus: A Hungarian pioneer in North America." In Explorers and Colonies: America, 1500-1625.

London/Ronceverte.

and N.M. Cheshire. 1972. The New Found Land of Stephen Parmenius: The Life and Writings of a Hungarian Poet, Drowned on a Voyage from Newfoundland, 1583. Toronto/Buffalo.

Raphaely, J. 1999. "Nothing but gibberish and shibboleths? The Compulsory Greek debates, 1871-1919.” In C.A. Stray, ed., Classics in 19th and 20th Century Cambridge: Curriculum, Culture and Community. Proceedings of the Cambridge Philological Society suppl. vol. 24. Cambridge.

Reeves, J.D. 1966. “The cause of the Trojan War: A forgotten myth revived.” Classical Journal 61: 211-214.

Reinhold, M. 1984. Classica Americana: The Greek and Roman Heritage in the 
United States. Detroit.

Reynolds, S. Medieval Reading: Grammar, Rhetoric and the Classical Text.

Cambridge Studies in Medieval Literature 27. Cambridge.

Rogers, J.D. 1931. A Historical Geography of the British Colonies. Vol. 5, pt.4:

Newfoundland. 2nd ed., revised by C.A. Harris. Oxford.

Rollmann, H. 2016. “Mullock and John Henry Newman.” In A. Ju-

hász-Ormsby and N. Earle, eds., The Finest Room in the Colony: The

Library of John Thomas Mullock. St. John's. 82-85.

and B. Power. 1989. "Bonavista's 'Hewers of wood and drawers of

water': The first school in Newfoundland." Bulletin of the Humanities

Association of Canada 17: 27-33.

Romm, J. 1993. "New World and 'novos orbes': Seneca in the Renaissance debate over ancient knowledge of the Americas." In W. Haase and M.

Reinhold, eds., The Classical Tradition and the Americas, vol. 1 (European Images of the Americas and the Classical Tradition, pt.1). Berlin/New York. 77-116.

Rose, H.J. 1937. "Wallace Martin Lindsay, 1858-1937." Proceedings of the British Academy 23: 487-512.

Rowe, F.W. 1952. The History of Education in Newfoundland. Toronto. - 1964. The Development of Education in Nerfoundland. Toronto.

Schipper, W. 2016. "A complete course in Theology: Jacques-Paul Migne." In A. Juhász-Ormsby and N. Earle, eds., The Finest Room in the Colony: The Library of John Thomas Mullock. St. John's. 70-71.

Siefker, P. 1997. Santa Claus, Last of the Wild Men: The Origins and Evolution of Saint Nicholas, Spanning 50,000 Years. Jefferson, NC/London.

Smith, B. 1931. "George Calvert at Oxford." Maryland Historical Magazine 26.2: 109-130.

Story, G.M. 1998. “McNeilly, Alexander James Whiteford.” In R. Cook, ed., Dictionary of Canadian Biography, vol. 14. Toronto/Buffalo/London. 730.

Stray, C.A. 1998. Classics Transformed: Schools, Universities, and Society in England, 1830-1960. Oxford.

Talbot, T. 1872. Ancient Philosophy; or, The Enchiridion of Epictetus, and Chrusa Epe of Pythagoras - translated into prose and verse, with large and copious notes, explanatory of the different systems of the Grecian philosophy; and scriptural references in illustration of the moral precepts inculcated by these philosophers. Montreal (also published London, 1881). 
1879. The Exile - and other verses together with translations from some of the Greek and Latin poets. London.

. 1881. Greece and the Greeks; or, a Historic Sketch of Attic Life and Manners. London.

-1882. Newfoundland: or, A Letter addressed to a Friend in Ireland in relation to the Conditions and Circumstances of the Island of Nerwfoundland, with an especial view to emigration. London.

Treggiari, S. 1985. “On Kipling's Horace.” Echos du monde classique 29: 421-433.

- 2012. "Kipling and the classical world."In The New Reader's Guide to the Works of Rudyard Kipling. http://www.kiplingsociety.co.uk/rg_classical1.htm.

Turner, F.M. 1981. The Greek Heritage in Victorian Britain. New Haven/ London.

Vance, N. 1993. "Horace and the nineteenth century." In C. Martindale and D. Hopkins, eds., Horace Made Nerw: Horatian Influences on British Writing from the Renaissance to the Twentieth Century. Cambridge. 199-216.

Whiteway, L. 1970-71. “The Athenaeum movement: St. John's Athenaeum (1861-1898).” Dalhousie Review 50: 534-549.

Williams, Jr., R.A. 1990. The American Indian in Western Legal Thought: The Discourses of Conquest. New York/Oxford.

Winkler, M.M. 2000. “Dulce et decorum est pro patria mori?’ Classical literature in the war film." International Journal of the Classical Tradition 7: 177-214. 